\title{
Gp100: ES209-217(210M) Peptide
}

National Cancer Institute

\section{Source}

National Cancer Institute. gp100: ES209-217(210M) Peptide. NCI Thesaurus. Code C2763.

A synthetic peptide vaccine consisting of amino acids 209 through 217 of the glycoprotein 100 (gp100) melanoma antigen with an endoplasmic reticulum signal sequence (ES) to increase binding activity. Vaccination with gp100:ES209-217(210M) may stimulate the host immune system to mount a cytotoxic $T$ lymphocyte response against tumor cells positive for gp100, resulting in decreased tumor growth. ( $\mathrm{NCI04)}$ 